FACTA UNIVERSITATIS

Series: Economics and Organization Vol. 13, No 4, 2016, pp. 379 - 386

DOI: 10.22190/FUEO1604379M

Preliminary communication

\title{
PROFITABILITY ANALYSIS OF MEAT INDUSTRY IN SERBIA
}

\author{
UDC 061.5:637.5(497.11)
}

\section{Kristina Mijić, Stanislav Zekić, Dejan Jakšić}

University of Novi Sad, Faculty of Economics Subotica, Serbia

\begin{abstract}
In this paper, profitability analysis of meat processing industry in Serbia was carried out for the period 2011-2015. Meat processing industry is one of the profitable sectors in the Republic of Serbia, with an average rate of ROA of 5.29. Even though companies in meat processing industry achieve positive net income, profitability is below referent value. In order to investigate which internal factors have a significant influence on the profitability of meat processing industry, a panel data regression was realized. The results show that companies with high liquidity ratio and growth in sales achieve better ROA. On the other hand, high debt ratio negatively influences the level of ROA. Furthermore, the results show that the size of the company, fixed assets ratio and rate of investment, do not have much influence on the profitability of meat processing industry.
\end{abstract}

Key words: Meat industry, profitability, internal profitability factors.

\section{INTRODUCTION - StATE AND PERSPECTIVE OF MEAT INDUSTRY IN SERBIA}

At the beginning of the global economic crisis, at the end of the first decade of the $21^{\text {st }}$ century, the Serbian academic and professional community established agro-economy sector as the bearer of economic development. Since it is clear that plant and animal production cannot be, due to the biological and economic constraints, all, the manufacturing sector is also placed as crucial for economic development. According to this, manufacturing sector, together with the agricultural production, presents an important agro-food system. The manufacturing sector, which is also known as agro-industry, includes also the manufacture of food, beverages, animal food and tobacco products. Food production, according to its importance, stands out from this group. Furthermore, processing of meat products also has an important place in this group. The importance of this sector, as well as the general processing sector, resulting from the conversion of raw materials into final products with greater value, which is, due to the relatively low level of finalization of Serbian agricultural production, important for the entire agricultural sector in Serbia.

Received September 26, 2016 / Accepted November 14, 2016

Corresponding author: Kristina Mijić

University of Novi Sad, Faculty of Economics, Segedinski put 9-11, 24000 Subotica Serbia

E-mail: mijick@ef.uns.ac.rs 
The meat industry is one of the major sectors, especially with significant increase of the added value of livestock production. The livestock is a generator of the intensity of agricultural production, and it can be a significant factor in the overall development of agroeconomy together with the developed sectors of processing livestock products. Also, the development of the meat industry would have positive effects on the agricultural holdings engaged in livestock production, which is very important for the social stability in rural areas. Furthermore, the development of the entire meat production chain will have a positive impact on the export performances of Serbian agro-economy, observed through the export value per unit of labor engaged and / or arable land. The reason is that meat and meat products are included in the agricultural products with the highest added value.

In the last ten years, in the period 2006-2015 the average annual production of meat in Serbia was over 460 thousand tons. The biggest part of that includes the production of pork - more than half of total meat production. In the second place is the production of beef and poultry, about $18 \%$ of each category. At the last place is the production of mutton- about $5 \%$. During this period there has been a decline in the production of two most common categories of meat, which is especially pronounced in beef, while the production of pork has the stagnant tendencies. The increase was present in the production of mutton, and the production of poultry has similar characteristics. Those tendencies are, of course, more or less in correlation with the movement of the number of certain categories of livestock units (Statistical Office of the Republic of Serbia).

The general characteristic of the manufacturing industry in Serbia is the low level of capacity utilization as a result of the political and economic environment of the former Yugoslavia where the majority of the capacity was created. In previous decades, this industry has shared the fate of agricultural production, so that after stagnation during the eighties, there was a decline in the nineties of the last century, which was accompanied by a reduction in employment in this sector. In the period after 2000 in Serbia, there was somegrowth of production in the manufacturing sector, but further employments reductions (Gajić M., S. Zekić, 2013). For meat production in Serbia, it is characteristic that only some of the animals are slaughtered in slaughterhouses, about $50 \%$, and this number varies depending on the type of livestock (the lowest is associated with sheep and the largest with poultry). The poultry industry represents the most industrialized livestock sector, among the whole of agriculture, so it is not surprising that in Serbia over $60 \%$ of the livestock are slaughtered in slaughterhouses. For cattle and pigs, this percentage is much smaller at $44 \%$ and $33 \%$, respectively. Keeping sheep in Serbia is characteristic of underdeveloped areas and small semi-subsistence farms, so the small share, about 5\% of sheep which are slaughtered in slaughterhouses, is relatively expected (Statistical Office of the Republic of Serbia). A large proportion of slaughtering on farms is quite typical for the more developed EU countries, where it has the marginal character.

In general, the most important factor in the economic viability of any manufacturing industry is the level of profitability that it achieves. Long-term profitability enables the achievement of economic growth and development. Furthermore, the identification of factors affecting the level of profitability is of great significance. These findings may represent useful information for companies operating in a particular sector, but also for the policies that should enable the propulsive development of certain economic sectors. In other words, the results of the study may represent strategic development guidelines, both for the individual production companies, as well as the entire sector. For this reason, the main goal of this paper is to analyze the factors of the profitability of the meat 
processing sector in the Republic of Serbia in the period 2011-2015. The first part of the research will give the answer to the question whether the meat processing sector is profitable. Furthermore, the analysis of trend and fluctuations in profitability will be conducted. The second part of the paper will identify the internal factors of companies that significantly affect the level of profitability of meat processing sector.

\section{DESCRIBE DATA AND Methodology}

\subsection{Profitability and profitability factors}

In order to analyze profitability and profitability factors, first, the profitability ratio as dependent variable and factors of profitability as independent variable are defined.

The profitability variable as a dependent variable can be represented by several ratios, such as return on assets, return on equity etc. According to Asiri (2015) the most relevant determinant in explaining the market value of enterprises is ROA, so the profitability of meat processing industry is represented by ROA. ROA is defined as the firm`s book value of net profit after tax divided by total assets.

On the other hand, as factors of profitability, or independent variables, were defined size, current ratio, leverage, fixed assets ratio, growth, and investment. The size of company can be measured by several proxies, such as natural logarithm of the assets, sales or employees. Larger companies have the ability to generate higher income, have better access to capital markets (Titman, Wessels, 1998), and lower cost of borrowing (Whited, 1992). According to this, it is expected that profitability and the size of company are positively related.

The current ratio measures the ability of the company to pay short-term liabilities. The current ratio is calculated as a ratio of current assets to current liabilities (Rodic, Vukelic, Andric, 2007). According to this, it is expected that greater firm ability to pay short-term liabilities is positively related to the profitability.

Leverage as a ratio of total debt to assets indicates the level of the company`s debt (Rodic, Vukelic, Andric, 2007). Higher debt can be negatively related to the profitability because high debt requires more resources to pay the debt.

Fixed assets to total assets ratio indicates the using of working capital and company`s ability to carry accounts receivable and maintain inventory. If the fixed assets ratio is 0.5 and higher, this will limit company`s ability to adequately react to increased demand. So, the higher fixed assets ratio is usually negatively related to the profitability (Pratheepan, 2014).

Growth is calculated as the growth rate of sales in two consecutive periods. If the firm achieves greater growth in sales, that means it provides additional income for the current period. Therefore it is expected that growth affects profitability positively (Asimakopoulos et al. 2009, Geroski et al. 1997).

Investment refers to increase in fixed assets, and it is calculated as the growth rate of gross fixed assets in two consecutive periods. It is expected that investment affects profitability positively since it expands production capacity, in order to improve sales and at the end to increase profit (Asimakopoulos et al. 2009; Guariglia, 2009). 
Table 1 Profitability and profitability factors

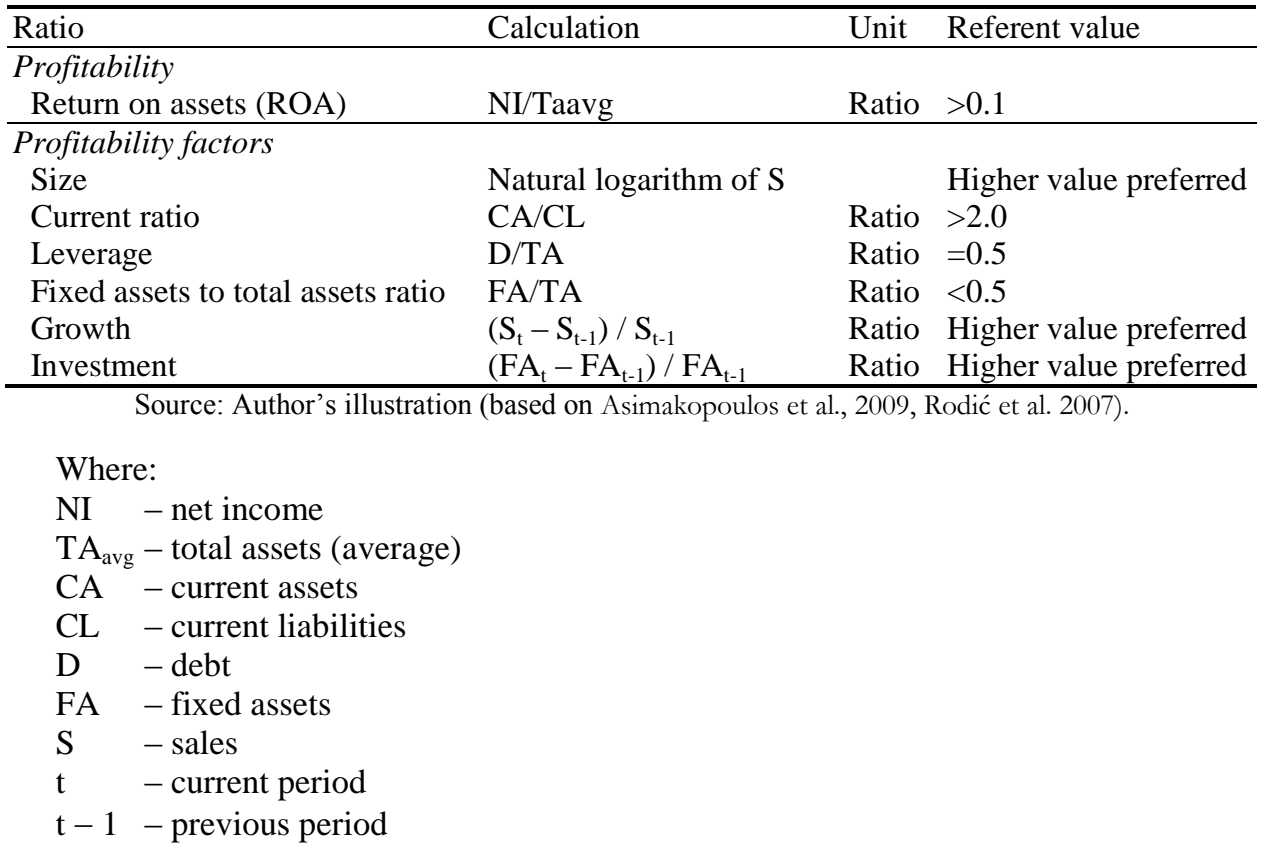

\subsection{Data}

The data used in this study refer to a sample of Serbian meat processing companies for the period 2011-2015. The data were collected from the database of Official Serbian Business Registers Agency, and include a detailed balance sheet, income statement, and other data on Serbian large and medium sized meat processing companies (Official Serbian Business Registers Agency, 2016). The original set includes 16 enterprises. In order to construct balanced panel data and avoid effects of new enterprises, and enterprises that shut down during the period, our sample consists of the enterprises that operated during the whole period 2011-2015. Furthermore, the missing or abnormal data were removed, so the final sample consists of 12 companies. Table 2 shows descriptive statistics of the dependent and independent variables of profitability for meat processing companies for the period 2011-2015.

Table 2 Descriptive statistics of profitability ratio and factors of profitability of meat industry in Serbia

\begin{tabular}{lcrrrr}
\hline Variable & Observation & \multicolumn{1}{c}{ Mean } & \multicolumn{1}{c}{ Std. Dev. } & \multicolumn{1}{c}{ Min } & \multicolumn{1}{c}{ Max } \\
\hline ROA & 60 & 0.0529 & 0.0439 & 0.0003 & 0.1796 \\
Size & 60 & 14.9804 & 1.0974 & 13.0753 & 16.8203 \\
Current ratio & 60 & 1.5557 & 0.6796 & 0.5544 & 3.4093 \\
Leverage & 60 & 0.5572 & 0.2256 & 0.1899 & 0.9453 \\
Fixed assets to total assets ratio & 60 & 0.5444 & 0.1137 & 0.3297 & 0.7578 \\
Growth & 60 & 0.1207 & 0.1879 & -0.3587 & 0.5359 \\
Investment & 60 & 0.1452 & 0.2527 & -0.3989 & 0.4018 \\
\hline
\end{tabular}


Meat processing companies in the Republic of Serbia achieve average positive profitability, but the level of profitability is below the referent value of 0.10 . The following table shows the profitability and factors of profitability during the period 2011-2015.

Table 3 Trend of profitability and profitability factors in the period 2011-2015

\begin{tabular}{lrrrrrr}
\hline Variable & \multicolumn{1}{c}{2011} & \multicolumn{1}{c}{2012} & \multicolumn{1}{c}{2013} & \multicolumn{1}{c}{2014} & \multicolumn{1}{c}{2015} & \multicolumn{1}{c}{$2011-2015$} \\
\hline ROA & 0.0442 & 0.0555 & 0.0603 & 0.0554 & 0.0588 & 0.0529 \\
Size & 14.6429 & 14.9315 & 14.8922 & 14.9943 & 14.9408 & 14.9804 \\
Current ratio & 1.4036 & 1.3515 & 1.6782 & 1.6292 & 1.5098 & 1.5557 \\
Leverage & 0.5643 & 0.5211 & 0.5831 & 0.5894 & 0.5382 & 0.5572 \\
Fixed assets to & 0.5354 & & & & & \\
total assets ratio & & 0.5027 & 0.5893 & 0.5563 & 0.5206 & 0.5444 \\
Growth & 0.1221 & 0.1316 & 0.1563 & 0.1187 & 0.1488 & 0.1207 \\
Investment & 0.1238 & 0.2437 & 0.0958 & 0.1589 & 0.1697 & 0.1452 \\
\hline \multicolumn{7}{c}{ Source: Author's calculation }
\end{tabular}

The profitability of meat processing companies has characteristics of fluctuation. Until 2013 profitability was in growth to 0.060 . Then, in 2014 the level of profitability has fallen down to 0.055 , and in the 2015 profitability has a little growth to 0.058 . If we compare the profitability in 2015 and 2011 it can be concluded that profitability level of meat processing companies raises for $30 \%$. Even though the profitability of meat processing companies is positive, they have a problem to achieve liquidity, because during the period 2011-2015 current ratio is below the 2 as referent value. The higher leverage than 0.5 indicates that the meat processing companies activities are financed more with debts than the capital. Furthermore, the leverage is very different among meat processing companies. The lowest leverage is 0.19 , while the highest leverage is 0.94 . The companies with lower leverage have the ability to increase profitability with additional debt. On the other hand, companies with high debt ratio have a problem to solve the current debt. Also, these companies do not have the ability to increase profit with additional debt. During the period 2011-2015, meat processing companies have growth in sales. Sales growth is on average 0.14 each year.

\subsection{Hypothesis and methodology}

In order to investigate profitability factors of large and medium sized meat processing companies in the Republic of Serbia a panel data techniques were conducted. According to this, the following hypothesis is defined.

$H_{0}$ : Firm internal characteristics, such as size, current ratio, leverage, fixed assets to total assets ratio, growth, and investment of Serbian meat processing companies have a significant impact on profitability.

A major motivation for using panel data has been the ability to control for possibly correlated, time-invariant heterogeneity without observing it (Williams, 2015). The two models, depending on the nature of the variables, are included into this estimation. If variables are constants over time, random effect model is better (Hsiao, 2010). Random effect model is given as (Bruderl, 2005):

$$
Y_{i t}=\beta_{0}+\beta_{1} X_{i t}+v_{i t}+\varepsilon_{i t}
$$


It is assumed that the $v_{i}$ are random variables (random effects) and that $\operatorname{Cov}\left(x_{i}, v_{i}\right)=$ 0 . Using a pooled-GLS estimator provides the random effects estimator. The following transformation is required to estimate random effects model from the pooled regression (Bruderl, 2005):

If independent variables vary over time, then the use of fixed effects model is appropriate.

$$
Y_{i t}=\beta_{1} X_{i t}+v_{i t}+\varepsilon_{i t}
$$

The answer to the question which model (fixed effects or random effects model) is appropriate will be realized by tests model validation such as Bresuch-Pagan Larange Multiplies test and Hausman test.

\section{RESULTS}

Table 4 summarizes the results of panel data regression analysis when random effect and fixed effect estimation were used for meat processing companies.

Table 4 Results of panel data regressions

\begin{tabular}{lcc}
\hline & \multicolumn{2}{c}{ Results } \\
\cline { 2 - 3 } Factors of ROA & Random effect & Fixed effect \\
\hline Size & 0.0041 & 0.0055 \\
Current ratio & $\mathbf{0 . 0 0 2 7}$ & $\mathbf{0 . 0 0 2 1}$ \\
Leverage & $\mathbf{- 0 . 0 6 6 8}$ & -0.0676 \\
Fixed assets to total assets ratio & 0.0656 & 0.0885 \\
Growth & $\mathbf{0 . 0 5 6 2}$ & $\mathbf{0 . 0 6 1 8}$ \\
Investment & 0.0039 & 0.0021 \\
\hline & R sq. $=0.4864$ & R sq. $=0.4908$ \\
& Prob $>$ chi $^{2}=0.004$ & Prob $>\mathrm{F}=0.003$ \\
\hline
\end{tabular}

Source: Author's calculation

Test and validation of the models were conducted before results interpretation. The selection of appropriate model between random effect and fixed effect is based on the Hausman test. The Hausman test result indicates the use of random effect model $(p=0.9680$ is greater than 0.05).

Table 5 Result of Hausman test

\begin{tabular}{lll}
\hline Test & Result & Conclusion \\
\hline $\begin{array}{l}\text { Hausman test }- \text { Testing of } \\
\text { random effect vs. fixed } \\
\text { effect model }\end{array}$ & $\mathrm{chi}^{2}(7)=(\mathrm{b}-\mathrm{B})^{\prime}\left[\left(\mathrm{V} \_\mathrm{b}-\mathrm{V} \_\mathrm{B}\right)^{\wedge}(-1)\right](\mathrm{b}-\mathrm{B})=1.36$ & $\begin{array}{l}\text { Random effect } \\
\text { model is } \\
\text { appropriate. }\end{array}$ \\
\hline
\end{tabular}

Source: Author's calculation

Based on the result reported in table 5 the following factors have a significant influence on the profitability of meat processing companies in Serbia: current ratio, leverage, and growth. On the other hand, independent variables such as size, fixed assets ratio, and investment are not significantly related to the profitability of meat processing industry. According to this findings, it can be concluded that hypothesis H1 is partially confirmed. 
The results indicate that current ratio and growth are positively related to the profitability. Meat processing companies with the higher current ratio, have a better ability to pay short-term liabilities, and also achieve better profitability. This is in accordance with findings of other authors (Barbosa and Louri, 2005; Kuntluru et al. 2008). Sales growth, as expected, positively influences a firm's profitability. The ability to increase the sales provides higher revenues as a positive component of net result.

On the other hand, leverage is negatively related to the profitability. This means that meat processing companies with high debt ratio have a lower net result. Higher debt negatively influences profitability because higher debt requires more resources to pay the debt. This finding is in accordance with the finding of Asimakopoulos et al. (2009) and Al-Jafari and Samman (2015).

\section{CONCLUSION}

The research results show that the meat industry in Serbia has been operating profitably, but the level of profitability was below the reference value in the period 20112015. Although at this time there are fluctuations in the level of profitability, there is a positive trend, so in 2015 the level of profitability of this industry is about $20 \%$ higher than in 2011.

The key factors that influence the level of profitability were identified: liquidity ratio and sales growth, with a positive impact, and the level of indebtedness that has a negative impact. There is a clear positive correlation between the growth and liquidity on the level of profitability, while the level of indebtedness, present in Serbian meat industry cannot have a positive impact on profitability. The reason is that the companies in meat processing sector have a problem of high debt ratio. The results indicate that meat processing companies do not use additional debt in investment that will increase profitability ratio. Debt ratio over referent value, and the situation that high debt ratio is negatively correlated to profitability, indicates that companies are more using additional borrowing to solve present debt and problems in business operations. In order to improve profitability ratio, meat processing companies first must reduce the level of indebtedness and start to use additional borrowing for adequate investment. On the other hand, the size of the company, the fixed assets ratio, and investment growth as factors of profitability are not significant variables for the companies in the meat processing industry in Serbia. These results are not surprising when you take into account previously expressed fact of oversized manufacturing industry, and one of its parts which was created in the period of centrally planned economy.

These results show that the growth in profitability in the meat industry will be significant with increasing capacity for utilization through sales growth. Also, great caution is required with borrowing, which should be directed towards the growth of competitiveness in the domestic and international market. The question of competitiveness is a very important one due to the process of European integration. The reason is that the entire agro-food sector in Serbia, including the meat industry, will be faced with a very high pressure by manufacturers from EU countries. 


\section{REFERENCES}

Asimakopoulos, I., Samitas, A., Papadogonas, T. (2009). Firm-specific and economy wide determinants of firm profitability-Greek evidence using panel data. Managerial Finance, 35 (11), 929-940.

Asiri, B. (2015). How investors perceive financial ratios at different growth opportunities and financial leverages. Journal of Business Studies Quarterly, 6 (3), 1-12.

Bruderl, J. (2005). Panel Data Analysis. Retrieved from: http://www2.sowi.uni-mannheim.de/lsssm/veranst/ Panelanalyse.pdf Accessed on: May 5, 2016

Gajić M., Zekić S. (2013). Development characteristics of agricultural sector in Serbia, in: ed. Škorić D., Tomic D., Popovic V.: Agri-food Sector in Serbia - state and Challenges, Monography; Serbian Association of Agricultural Economists, and Serbian Academy of Science and Art - Board for Village, Belgrade; 73-90.

Geroski, P. A., Machin, S. J., Walters, C. F. (1997). Corporate growth and profitability. The Journal of Industrial Economics, 45 (2), 171-189.

Guariglia, A. (2009). Modeling the relationship between financial indicators and company performance - an empirical study for US listed companies. Dissertation. Vienna University of Economics and Business Administration.

Official Serbian Business Registers Agency (2016). Database. Retrieved from: http://www.apr.gov.rs Accessed on: September 5, 2016

Pratheepan, T. (2014). A Panel data analysis of profitability determinants: Empirical results from Sri Lankan manufacturing companies. International Journal of Economics, Commerce and Managemen,. 2 (12), 1-9.

Rodić, J., Vukelić, G., Andrić, M. (2007). Teorija, politika i analiza bilansa. Beograd: Beoknjiga.

Statistical Office of the Republic of Serbia. (2012). Electronic Databases. Retrieved from: http://webrzs.stat.gov.rs Accessed on: July 28, 2016.

Titman, S., Wessels, R. (1988). The determinants of capital structure choice. Journal of Finance, (43), 1-19.

Whited, T. (1992). Debt, liquidity constraints and corporate investment: evidence from panel data. Journal of Finance, (47), 1425-1460.

Williams, R. (2015). Panel Data: Very Brief Overview. Retrieved from: https://www3.nd.edu/ rwilliam/stats2/ Panel.pdf Accessed on: May, 102016.

\section{ANALIZA PROFITABILNOSTI MESNE INDUSTRIJE U SRBIJI}

U radu je sprovedena analiza profitabinosti mesne prerađivačke industrije u Srbiji u periodu 2011-2015. godina. Mesna prerađivačka industrija je profitabilna, uz ostvarivanje prosečne stope profitabilnosti od 5.29. I pored konstantnog poslovanja sa dobitkom, preduzeća u okviru ovog sektora ne uspevaju da ostvare referentni nivo profitabilnosti. U cilju ispitivanja koji interni faktori utiču na profitabilnost preduzeća u mesnoj prerađivačkoj industriji, sprovedena je regresiona analiza na bazi panel podataka. Rezultati ukazuju da preduzeća sa visokim raciom likvidnosti $i$ pozitivnom stopom rasta prodaje ostvaruju bolju profitabilnost. Sa druge strane, visok stepen zaduženosti je negativno povezan sa stepenom profitabilnosti preduzeća. Dalje, rezultati su ukazali da veličina preduzeća, racio fiksne imovine i nivo investija ne predstavljau značajne faktore koji utiču na smer i intenzitet profiabilnosti mesne industrije u Srbiji.

Ključne reči: mesna industrija, profitabilnost, interni faktori profitabilnosti. 